\title{
Specify Other Spinal/Epidural Anesthesia Agents Administered
}

National Cancer Institute

\section{Source}

National Cancer Institute. Specify Other Spinal/Epidural Anesthesia Agents Administered. NCI Thesaurus. Code C162678.

A request to specify epidural/spinal agents that were administered but not included on a list. 